\title{
Mechanisms of Alzheimer's Disease Pathogenesis and Prevention: The Brain, Neural Pathology, N-methyl-D-aspartate Receptors, Tau Protein and Other Risk Factors
}

\author{
Sayad Kocahan ${ }^{1,2}$, Zumrut Doğan ${ }^{3}$ \\ Departments of ${ }^{1}$ Physiology and ${ }^{3}$ Anatomy, Faculty of Medicine, Adiyaman University, Adiyaman, Turkey, ${ }^{2}$ International Scientific Center, \\ Baku State University, Baku, Azerbaijan
}

\begin{abstract}
The characteristic features of Alzheimer's disease (AD) are the appearance of extracellular amyloid-beta (A $\beta$ ) plaques and neurofibrillary tangles in the intracellular environment, neuronal death and the loss of synapses, all of which contribute to cognitive decline in a progressive manner. A number of hypotheses have been advanced to explain $A D$. Abnormal tau phosphorylation may contribute to the formation of abnormal neurofibrillary structures. Many different structures are susceptible to $A D$, including the reticular formation, the nuclei in the brain stem (e.g., raphe nucleus), thalamus, hypothalamus, locus ceruleus, amygdala, substantia nigra, striatum, and claustrum. Excitotoxicity results from continuous, low-level activation of N-methyl-D-aspartate (NMDA) receptors. Premature synaptotoxicity, changes in neurotransmitter expression, neurophils loss, accumulation of amyloid $\beta$-protein deposits (amyloid/senile plaques), and neuronal loss and brain atrophy are all associated with stages of $A D$ progression. Several recent studies have examined the relationship between A $\beta$ and NMDA receptors. A $\beta$-induced spine loss is associated with a decrease in glutamate receptors and is dependent upon the calcium-dependent phosphatase calcineurin, which has also been linked to long-term depression.
\end{abstract}

KEY WORDS: Alzheimer's disease; Amyloid $\beta$; N-Methyl-D-Aspartate; Neurodegeneration; Tau; Genetically modified animals.

\section{INTRODUCTION}

Dementia in the elderly population is most commonly caused by Alzheimer's disease (AD). The characteristic features of $\mathrm{AD}$ are the appearance of extracellular amyloid- $\beta(\mathrm{A} \beta)$ plaques and neurofibrillary tangles in the intracellular environment, neuronal death and the loss of synapses, all of which contribute to cognitive decline in a progressive manner. $\mathrm{AD}$ is a terminal and incurable disease. ${ }^{1)}$ The most $\mathrm{AD}$ important risk factor is age, with the prevalence of $\mathrm{AD}$ rising exponentially after 65 years of age., ${ }^{2,3)}$ The overall prevalence of $\mathrm{AD}$ is expected to double within 20 years as average lifespan increases in developing nations.

Neurodegenerative conditions associated with cogni-

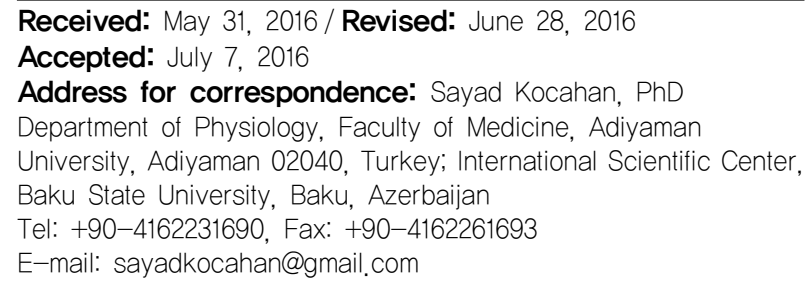

tive decline, including $\mathrm{AD}$, are frequently associated with changes in the number and shape of dendritic spines prior to neuronal death. ${ }^{4,5)}$ Neurodegeneration in AD patients is characterized by changes in neurotransmitter expression, reduced neutrophil numbers, synaptotoxicity, accumulation of $\mathrm{A} \beta$-protein deposits (amyloid/senile plaques), and large scale neuronal death and neural atrophy in the final phase of the disease. ${ }^{6-10)}$ A number of studies have suggested that $A \beta$ accumulation may contribute to dendritic spine loss. ${ }^{4,5)}$ Deficits in memory and other cognitive functions in the initial stages of the disease are associated with changes in the hippocamus and the entorhinal cortex. ${ }^{11)}$ As many as $80 \%$ of the neurons in the hippocampus may die over the course of $\mathrm{AD}$, and this progressive loss is manifest in the cognitive changes and other symptoms seen in AD patients. ${ }^{9,11)}$

In this review article, we will summarize the anatomy, pathogenesis, neural mechanisms, the role of tau, N-methyl-D-aspartate (NMDA) receptors and brain-derived neurotrophic factor (BDNF), animal models, risk factors, and prevention of $\mathrm{AD}$. These topics are of critical importance due to the ever-increasing prevalence of $\mathrm{AD}$.

(a) This is an Open-Access article distributed under the terms of the Creative Commons Attribution Non-Commercial License (http://creativecommons.org/licenses/by-nc/4.0) which permits unrestricted non-commercial use, distribution, and reproduction in any medium, provided the original work is properly cited. 


\section{BRAIN AND ANATOMY}

Memory functions are primarily mediated by the hippocampus and it's associated structures (e.g., subiculum, dentate gyrus, parasubiculum, presubiculum, and entorhinal cortex). ${ }^{12-14)}$ Accelerated hipocampal atrophy that is especially marked in the frontal-temporal horn and atrophy of the cerebral cortex is associated with AD. Earlyphase neurocognitive symptoms of $\mathrm{AD}$ include memory and spatial learning deficits, both functions associated with the hippocampus. ${ }^{15-19)}$ Application of $A \beta$ oligomers reduces the density of spines in organotypic hippocampal slice cultures and dissociated cultured neurons. ${ }^{20-24)}$ Significant atrophy of the entorhinal cortex occurs in AD and histological evaluation reveals neuronal degenerations and the presence of neurofibrillary tangles within layers II-IV. Neuritic plaques are frequently seen in layer III, while layers V and VI have relatively fewer neurofibrillary tangles compared to layers II and IV. ${ }^{14,25,26)}$ In addition, neuronal loss in layer II damages the perforant pathway or the projection of the entothinal cortex into the hippocampus. Efferent connections from the hippocampus to the cortex are inhibited by the progressive degeneration of neurons from layer IV. ${ }^{14,27)}$ Furthermore, damage to layer IV and layer II within the entorhinal cortex has been associated with pathological alterations in the closely related hippocampal formation. Prominent neuronal atrophy and neurofibrillary tangle deposition are seen in the CA1 region of the hippocampus. ${ }^{14,28)}$

\section{NEURAL MECHANISMS}

Cell types affected by AD include: locus ceruleus, the nuclei of the brain stem (e.g., raphe nucleus), reticular formation, amygdala, substantia nigra, striatum, hypothalamus, thalamus, and claustrum, and select regions of the cerebral cortex. The neuronal types affected vary by region according to the expression of neurotransmitters, neuromodulators, and neuropeptides. The degenerative process results in cerebral atrophy and neuron loss. ${ }^{29-32)}$ Disease pathobiology affects non-neuronal cells as well; oligodendroglia, astrocytes, blood vessels, microglia, and the choroid plexus all undergo degenerative processes. Transgenic mouse models of AD indicated that amypoid plaques occur in the vicinity of structural changes capable of altering brain function, including neurite dystrophy and spine loss. ${ }^{5,33-36)}$ Synaptic loss strongly correlates with cognitive deficits in AD. Synapse loss is likely a morphological reflection of the synaptic dysfunction that begins early in the disease. ${ }^{33,37-40)}$ Early structural studies of postmortem brain tissues demonstrated that AD patients exhibited a reduced number of dendritic spines and reduced synapse density in the hippocampus and cortex relative to age-matched control brain tissues. There was a direct correlation between increased dendritic spine loss and worsening mental status. The progressive atrophy of dendritic spines is therefore proportional to AD pathogenesis and may represent accurate indicator of advancing disease. ${ }^{5,41)}$

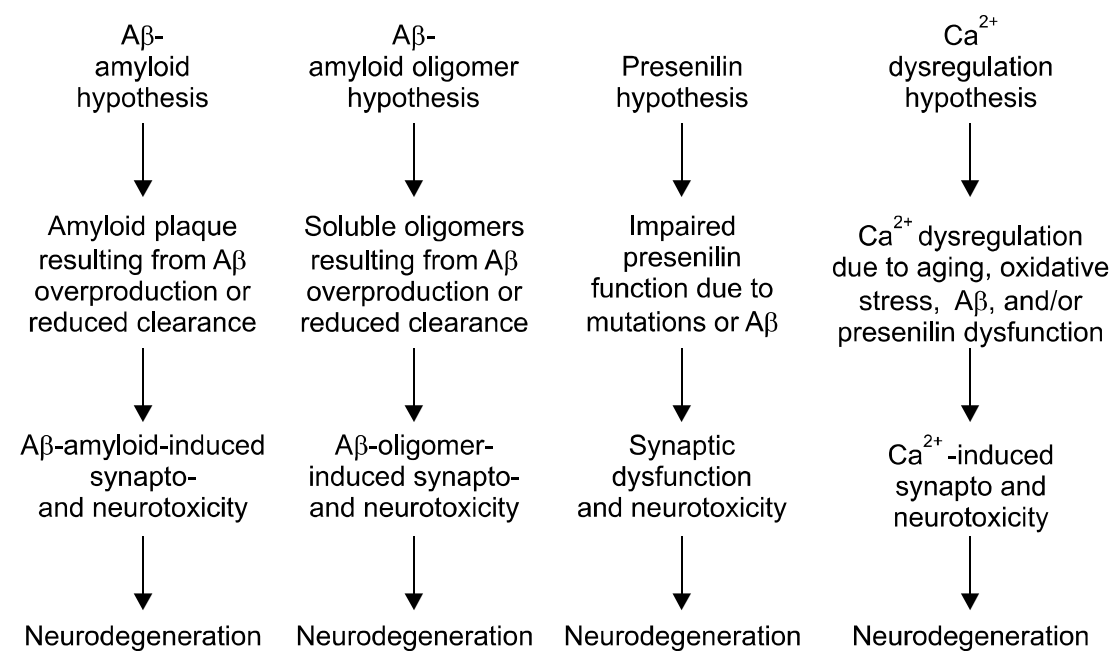

Fig. 1. Pathogenic hypotheses for synaptic and neuronal toxicity in Alzheimer's disease.
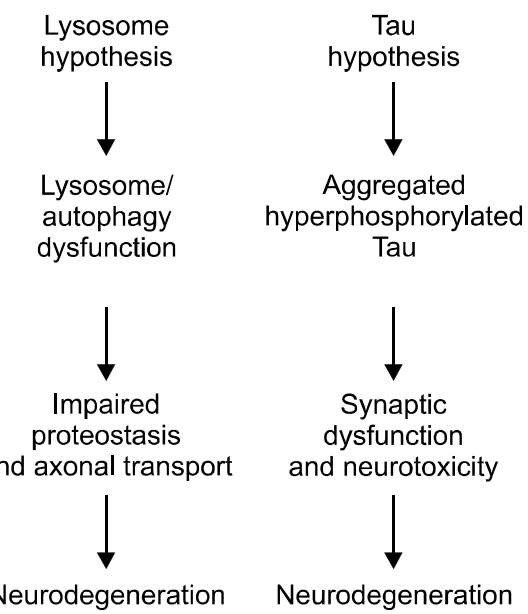


\section{PATHOGENESIS OF ALZHEIMER'S DISEASE}

A number of hypotheses have been proposed that may explain AD pathogenesis: (a) the $\mathrm{A} \beta$-amyloid hypothesis, (b) the $A \beta$-amyloid oligomer hypothesis, (c) the presenilin hypothesis, (d) the $\mathrm{Ca}^{2+}$ dysregulation hypothesis, (e) the lysosome hypothesis, and (f) the tau hypothesis (Fig. 1). Although the amyloid hypothesis is the best-developed hypothesis, ${ }^{42,43)}$ multiple reports have suggested a weak correlation between $A \beta$ deposition and neuronal atrophy and cognitive impairment. ${ }^{43,44)}$

$\mathrm{A} \beta$ is the most widely studied component of $\mathrm{AD}$ pathogenesis. The isolation and partial sequencing of the meningovascular $\mathrm{A} \beta$ by George Glenner and Caine Wong in 1984 was a turning point for modern research of the fundamental mechanisms of AD. ${ }^{45)}$ Multiple forms of $A \beta$ are derived by proteolytic cleavage from the type I cell-surface protein amyloid precursor protein (APP). The amyloid hypothesis broadly posits that excessive amounts of $\mathrm{A} \beta$ peptide in the brain (particularly $\mathrm{A} \beta 42$ ) are responsible for AD-related pathology, including amyloid plaques, neurofibrillary tangles, synapse loss, and eventual neuronal cell death. ${ }^{2,3,46,47)}$

Imaging of amyloid plaques reveals the rapid formation of plaque structures over a 24 hour time period; dystrophic swelling of adjacent dendrites begins to appear within one week. $^{48,49)}$ Instability of spines in the vicinity of $A \beta$ plaques reflects dynamically dysfunctional plasticity in neuronal structures. These processes enhance functional deficit in the regions surrounding plaques. ${ }^{48)}$

\section{ALZHEIMER'S DISEASE AND NMDA RECEPTORS}

Glutamate is the principal excitatory neurotransmitter of the Central Nervous System (CNS). Glutamate mediates neuronal plasticity, neural transmission, memory processes, and learning. ${ }^{50)}$ The pathogenesis of $\mathrm{AD}$ is strongly associated with alterations in glutamate signaling and the tissues affected by AD contain high densities of glumatergic neurons. ${ }^{9,51-56)}$ Early degeneration occurs to the neocortex pyramidal neurons of layers $\mathrm{V}$ and $\mathrm{III}^{57,58)}$ and to the glutamate-innervated cortical and hippocampal neurons. ${ }^{59)}$ 'Excitotoxicity' occurs as a result of the chronic, moderate activation of NMDA receptors, leading to neurodegeneration. ${ }^{9,60-63)}$ The excitotoxicity hypothesis is supported by clinical evidence indicating that the NMDA receptor antagonist memantine slows AD progression. ${ }^{64)}$ Prolonged $\mathrm{Ca}^{2+}$ elevation suppresses synaptic function, leading to subsequent synaptotoxicity and eventually atrophy; these events correlate with the loss of learning and memory functions in $\mathrm{AD}{ }^{56,64,65)}$ Multiple neurotrophic factors have been demonstrated to enhance defense against excitotoxicity. Fibroblast growth factor treatment alters expression of NMDA receptors in cultured cortical and hippocampal neurons, protecting against glutamate toxicity. ${ }^{66)}$

NMDA receptors mediate synaptic plasticity, critical for memory and learning functions, through long-term potentiation (LTP). ${ }^{67-69)}$ Synaptic plasticity is an essential component of memory and learning. ${ }^{5,70)}$ LTP of synaptic transmission and permanently altered expression of post-synaptic AMPA ( $\alpha$-amino-3-hydroxy-5-methyl-4isoxazolepropionic acid) receptors occurs as a result of high levels of synaptic activity and open NMDA receptors. ${ }^{71)}$ However, mild synaptic stimulation elicits long-term depression (LTD) in active NMDA receptors. ${ }^{5,72)}$ Several recent studies have examined the relationship between $A \beta$ and NMDA. ${ }^{73)} A \beta$-induced spine loss is associated with a decrease in glutamate receptors, also required for LTD, in a calcineurin-dependent manner. ${ }^{3,20,74-76)}$ It is widely believed that the synaptic dysfunction and synapse loss contribute to the cognitive deficits of patients with $\mathrm{AD}$.

There are a variety of potential links between $A \beta$ and the NMDA receptor: 1) NMDA receptor may bind $A \beta$ directly or through indirect interactions; 2) NMDA receptors may mediate $A \beta$ activity relative to plasticity and/or synaptic transmission; 3) NMDA may be a downstream target of $A \beta$, meaning that $A \beta$ mediates the function of NMDA receptors; 4) NMDA signaling may influence the assembly of $A \beta$ plaques (Fig. 2).

\section{TAU PROTEIN}

The accumulation of the protein tau within the brain tissue of AD patients was first described in $1986 .{ }^{77,78)}$ Tau phosphorylation was also proposed as a potential contributor to the formation of neurofibrillary tangles in $\mathrm{AD} .^{78-80)}$ In patients with $\mathrm{AD}$, hyperphosphorylation of certain amino acids in tau proteins causes the proteins to dissociate from the microtubules, disturbing the transport structure and resulting in starvation of neurons and, ultimately, cell death. Hyperphosphorylated tau thus has an important role in intracellular neurofibrillary changes and the pathogenesis of AD and related tauopathies. ${ }^{81,82)}$

CNS dendrites primarily express the axonal protein tau. ${ }^{83)}$ Tau mediates transfer of Fyn, a Src kinase, to the dendritic compartment; Fyn subsequently phosphorylates 


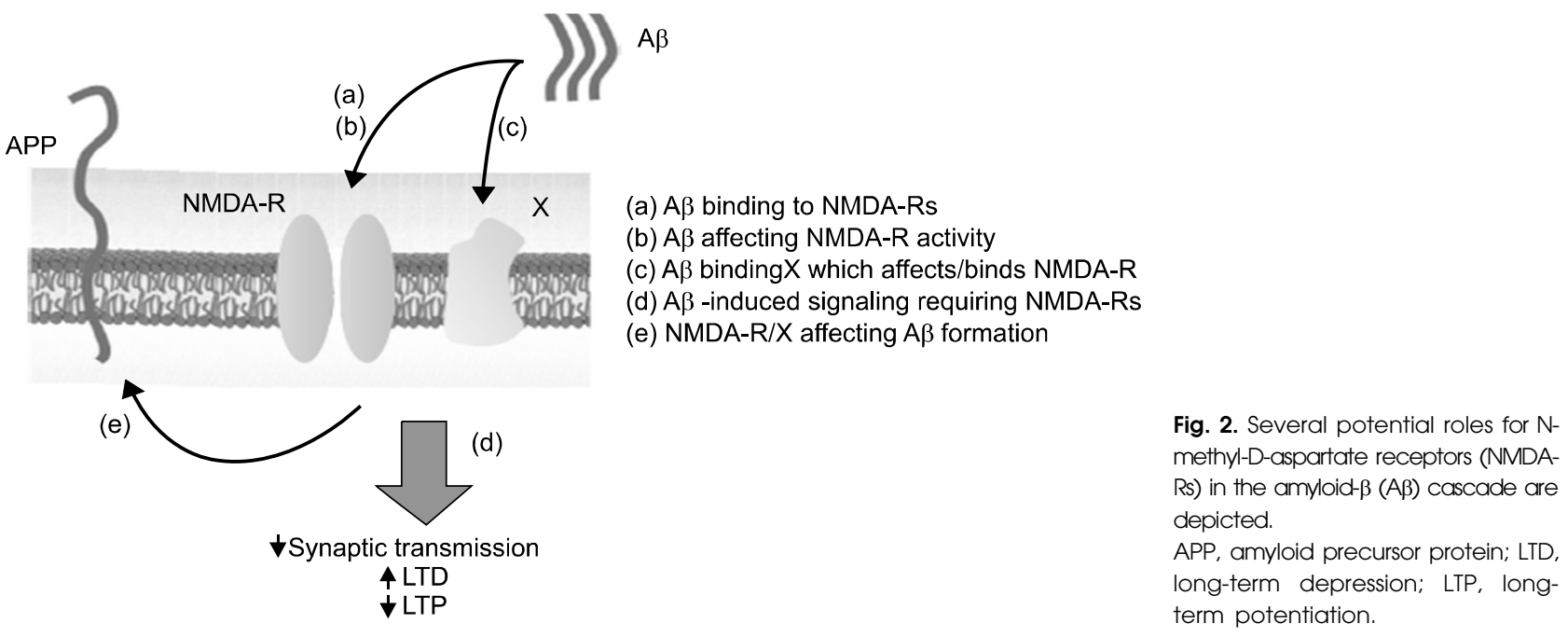

NMDA, facilitating an interaction with the post-synaptic density protein 95 (PSD95). In studies involving APP transgenic $\left(\mathrm{APP}^{\mathrm{tg}}\right)$ APP23 mice, the PSD95 complex exerts toxic effects in concert with $A \beta$, resulting in as evidenced by marked functional deficits in memory, increased excitotoxicity, and death. ${ }^{84)}$ Reductions in fast axonal transport and microtubule density tau transgenic mice are associated with amyotrophy, axonopathy, and motor deficits. $^{84-86)}$

\section{BRAIN-DERIVED NEUROTROPHIC FACTOR AND ALZHEIMER'S DISEASE}

BDNF, a growth factor included within the neurotrophin family, is a critical mediator of neuronal survival, synaptic plasticity, and cellular differentiation. In addition to these well-established cell survival functions, BDNF contributes to cognitive activity learning, behavior, and memory. ${ }^{87,88)}$ Low expression of BDNF mRNA in the nucleus basalis of Meynert, the neocortex, and the hippocampus has been reported in postmortem samples taken from AD patients. ${ }^{89-92)}$ Immediate, transient hippocampal elevation of BDNF mRNA levels occurs in mice during the execution of passive avoidance tests, hippocampusdependent learning in the Morris water maze and contextual fear tests. Anti-BDNF antibodies induce impaired memory in mice during the passive avoidance and water maze tests. ${ }^{93-95)}$ Impaired LTP of the hippocampus occurs in mice deficient in neuronal BDNF; LTP can be restored in these animals following administration of BDNF. ${ }^{96)}$

Cognitive decline occurs as the result of acetylcholine inhibition brought on by atrophy of cholinergic neurons in the forebrain of $\mathrm{AD}$ patients. BDNF enhances differ- entiation and survival of cholinergic neurons in the basal forebrain. Importantly BDNF induces the secretion of acetylcholine in basal forebrain neurons; acetylcholine is deficient in AD. ${ }^{97,98)}$ Cumulatively, preclinical observations have suggested that deficient BDNF synthesis contributes to neuronal dysfunction in $\mathrm{AD}$.

\section{ANIMAL MODELS AND BEHAVIOR}

Memory and learning are dependent upon alterations in synaptic transmission within the hippocampus and other areas of the brain. Transgenic animals that over-express $\mathrm{A} \beta$ accurately model familial-type $\mathrm{AD}$ and may contribute to increased understanding of the pathogenesis of cognitive and memory deficits. ${ }^{5,99)}$ Synaptic function and plasticity have been extensively studied in transgenic APP and APP/PS mice, with a focus on the dentate gyrus and CA1 subfields of the hippocampus. AD transgenic mice show abnormal synaptic transmission and impaired LTP, often well in advance of plaque formation. ${ }^{3,100-102)}$ Memory and learning deficits may occur within 3 months in mouse models, suggesting that soluble $A \beta$ contributes to $\mathrm{AD}$ pathogenesis. ${ }^{103,104)}$ Alternate studies report later onset of symptoms at more advanced ages, implicating insoluble $A \beta$ plaques. ${ }^{100,104-109)}$ The specific structure of $A \beta$ that is responsible for cognitive deficits has been the subject of great debate. Amygdala-dependent learning is strongly inhibited with increasing age in $\mathrm{Tg} 2576$ mice models, suggesting that the amygdala is susceptible to $A \beta$ toxcicity. ${ }^{35,110,111)}$ 


\section{RISK FACTORS}

Several risk factors of $\mathrm{AD}$ development have been reported, including psychosocial, genetic, and vascular parameters. AD may be classified as early ( $<65$ years) and late (60 to 65 years) onset disease. Late-onset AD is associated with strong genetic heritability, perhaps as high as $58-79 \%$. Autosomal dominant mutations in the genes for presenilin 1 and 2 and APP are found in earl-onset, familial disease. Vascular risk factors (e.g., obesity, tobacco use, and blood cholesterol) and vascular diseases (e.g., diabetes mellitus, hypertension, and stroke) dare linked to an elevated risk of AD. Psychosocial factors such as low educational level, lack of social engagement, and poor social networking have also been associated with increased risk of $\mathrm{AD}{ }^{1,112,113)}$

\section{COGNITIVE RESERVE AND PREVENTION}

The quantitative function known as brain reserve has wide ranging biological implications for the pathogenesis of AD. For example, environmental stimuli trigger upregulation of BDNF and neurogenesis, ${ }^{114-116)}$ encouraging neural plasticity. ${ }^{116,117)}$ Cognitive and brain reserves, enhance our understanding of the differences in the clinical pathology of the brains of AD patients. ${ }^{114,116)}$ A number of studies have evaluated the association between leisure activities and AD incidence. ${ }^{114)}$ Engagement in intellectual activities (e.g., games, reading, or coursework) or social activities (e.g., maintaining close relationships with friends and relatives) was assessed in a large cohort of elderly New Yorkers who had not been diagnosed with AD; individuals engaged in numerous leisure activities had a dramatically reduced risk of developing AD during follow-up evaluation. ${ }^{118,119)}$

\section{CONCLUSIONS}

The principle aim this review article was to discuss the neuronal impairments associated with AD. A variety of interesting theories are emerging, including different perspectives on hypotheses such as the $\mathrm{A} \beta$ cascade, $\mathrm{Ca}^{2+}$ dysregulation, tau hyperphosphorylation, and lysosome hypotheses. Various hypotheses related to AD play key roles in developing remedies and treatments. The use of animal models can shed light on research. The available evidence indicates that glutamatergic system, including NMDA receptors, contributes significantly to neuronal atrophy and synaptic dysfunction triggered by $A \beta$. Results have demonstrated low brain BDNF mRNA expression in patients with $\mathrm{AD}$, including the hippocampus, which is responsible for learning and memory.

\section{REFERENCES}

1. Povova J, Ambroz P, Bar M, Pavukova V, Sery O, Tomaskova $\mathrm{H}$, et al. Epidemiological of and risk factors for Alzheimer's disease: a review. Biomed Pap Med Fac Univ Palacky Olomouc Czech Repub 2012;156:108-114.

2. Blennow K, de Leon MJ, Zetterberg H. Alzheimer's disease. Lancet 2006;368:387-403.

3. Sheng M, Sabatini BL, Südhof TC. Synapses and Alzheimer's disease. Cold Spring Harb Perspect Biol 2012;4:a005777.

4. Selkoe DJ. Soluble oligomers of the amyloid beta-protein impair synaptic plasticity and behavior. Behav Brain Res 2008;192:106-113.

5. Yu W, Lu B. Synapses and dendritic spines as pathogenic targets in Alzheimer's disease. Neural Plast 2012;2012: 247150.

6. Yankner BA. Mechanisms of neuronal degeneration in Alzheimer's disease. Neuron 1996;16:921-932.

7. Bell KF, Claudio Cuello A. Altered synaptic function in Alzheimer's disease. Eur J Pharmacol 2006;545:11-21.

8. Citron M. Alzheimer's disease: strategies for disease modification. Nat Rev Drug Discov 2010;9:387-398.

9. Danysz W, Parsons CG. Alzheimer's disease, $\beta$-amyloid, glutamate, NMDA receptors and memantine--searching for the connections. Br J Pharmacol 2012;167:324-352.

10. Braak H, Braak E, Bohl J. Staging of Alzheimer-related cortical destruction. Eur Neurol 1993;33:403-408.

11. Morris RG, Kopelman MD. The memory deficits in Alzheimer-type dementia: a review. $Q J$ Exp Psychol A 1986;38:575-602.

12. Wang SH, Morris RG. Hippocampal-neocortical interactions in memory formation, consolidation, and reconsolidation. Annu Rev Psychol 2010;61:49-79, C1-C4.

13. D'Amelio M, Rossini PM. Brain excitability and connectivity of neuronal assemblies in Alzheimer's disease: from animal models to human findings. Prog Neurobiol 2012;99:42-60.

14. Walsh DM, Selkoe DJ. Deciphering the molecular basis of memory failure in Alzheimer's disease. Neuron 2004;44: 181-193.

15. Alves L, Correia AS, Miguel R, Alegria P, Bugalho P. Alzheimer's disease: a clinical practice-oriented review. Front Neurol 2012;3:63.

16. Perl DP. Neuropathology of Alzheimer's disease. Mt Sinai $J$ Med 2010;77:32-42.

17. Hort J, Laczó J, Vyhnálek M, Bojar M, Bures J, Vlcek K. Spatial navigation deficit in amnestic mild cognitive impairment. Proc Natl Acad Sci U S A 2007;104:4042-4047.

18. Yamin G. NMDA receptor-dependent signaling pathways that underlie amyloid beta-protein disruption of LTP in the hippocampus. J Neurosci Res 2009;87:1729-1736.

19. Hsieh H, Boehm J, Sato C, Iwatsubo T, Tomita T, Sisodia $\mathrm{S}$, et al. AMPAR removal underlies Abeta-induced synaptic depression and dendritic spine loss. Neuron 2006;52:831-843.

20. Calabrese B, Shaked GM, Tabarean IV, Braga J, Koo EH, Halpain S. Rapid, concurrent alterations in pre-and postsynaptic structure induced by naturally-secreted amyloidbeta protein. Mol Cell Neurosci 2007;35:183-193.

21. Lacor PN, Buniel MC, Furlow PW, Clemente AS, Velasco 
PT, Wood M, et al. Abeta oligomer-induced aberrations in synapse composition, shape, and density provide a molecular basis for loss of connectivity in Alzheimer's disease. $J$ Neurosci 2007;27:796-807.

22. Shankar GM, Li S, Mehta TH, Garcia-Munoz A, Shepardson NE, Smith I, et al. Amyloid-beta protein dimers isolated directly from Alzheimer's brains impair synaptic plasticity and memory. Nat Med 2008;14:837-842.

23. Wei W, Nguyen LN, Kessels HW, Hagiwara H, Sisodia S, Malinow R. Amyloid beta from axons and dendrites reduces local spine number and plasticity. Nat Neurosci 2010;13:190-196.

24. Hyman BT, Van Hoesen GW, Damasio AR, Barnes CL. Alzheimer's disease: cell-specific pathology isolates the hippocampal formation. Science 1984;225:1168-1170.

25. Hyman BT, Van Hoesen GW, Kromer, LJ, Damasio AR. Perforant pathway changes and the memory impairment of Alzheimer's disease. Ann Neurol 1986;20:472-481.

26. Hardy J, Revesz T. The spread of neurodegenerative disease. N Engl J Med 2012;366:2126-2128.

27. Arriagada PV, Growdon JH, Hedley-Whyte ET, Hyman BT. Neurofibrillary tangles but not senile plaques parallel duration and severity of Alzheimer's disease. Neurology 1992;42:631-639.

28. Hof PR. Regional and laminar patterns of selective neuronal vulnerability in Alzheimer's disease. In: Hof PR, Mobbs CV, editors. Functional neurobiology of aging. San Diego, San Francisco, New York, Boston, London, Sydney, Tokyo:Academic Press;2001. p.95-110.

29. Vogt BA, Vogt LJ, Hof PR. Patterns of cortical neurodegeneration in Alzheimer's disease: subgroups, subtypes, and implications for staging strategies. In: Hof $P R$, Mobbs CV, editors. Functional neurobiology of aging. San Diego, San Francisco, New York, Boston, London, Sydney, Tokyo:Academic Press;2001. p.111-130.

30. Duyckaerts C, Dickson DW. Neuropathology of Alzheimer's disease and its variants. In: Dickson DW, Weller RO, editors. Neurodegeneration: the molecular pathology of dementia and movement disorders. Chichester:Wiley-Blackwell; 2011. p.47-65.

31. Lowe J, Mirra SS, Hyman B, Dickson DW. Ageing and dementia. In: Love S, Louis DN, Ellison DW, editors. Greenfield's neuropathology. London:Hodder Arnold;2008. p.1031-1152.

32. Ferrer I. Defining Alzheimer as a common age-related neurodegenerative process not inevitably leading to dementia. Prog Neurobiol 2012;97:38-51.

33. Tsai J, Grutzendler J, Duff K, Gan WB. Fibrillar amyloid deposition leads to local synaptic abnormalities and breakage of neuronal branches. Nat Neurosci 2004;7: 1181-1183.

34. Spires TL, Meyer-Luehmann M, Stern EA, McLean PJ, Skoch J, Nquen PT, et al. Dendritic spine abnormalities in amyloid precursor protein transgenic mice demonstrated by gene transfer and intravital multiphoton microscopy. $J$ Neurosci 2005;25:7278-7287.

35. Spires-Jones TL, Meyer-Luehmann M, Osetek JD, Jones $\mathrm{PB}$, Stern EA, Baskai BJ, et al. Impaired spine stability underlies plaque-related spine loss in an Alzheimer's disease mouse model. Am J Pathol 2007;171:1304-1311.

36. Terry RD, Masliah E, Salmon DP, Butters N, DeTeresa R, Hill R, et al. Physical basis of cognitive alterations in Alzheimer's disease: synapse loss is the major correlate of cognitive impairment. Ann Neurol 1991;30:572-580.

37. Selkoe DJ. Alzheimer's disease is a synaptic failure.
Science 2002;298:789-791.

38. Arendt T. Synaptic plasticity and cell cycle activation in neurons are alternative effector pathways: the 'Dr. Jekyll and Mr. Hyde concept' of Alzheimer's disease or the yin and yang of neuroplasticity. Prog Neurobiol 2003;71: 83-248.

39. Bloss EB, Morrison JH, Hof PR, Dickstein DL. Influence of aging and neurodegeneration on dendritic spine morphology. Transl Neurosci 2011;2:49-60.

40. Dekosky ST, Scheff SW. Synapse loss in frontal cortex biopsies in Alzheimer's disease: correlation with cognitive severity. Ann Neurol 1990;27:457-464.

41. Selkoe D. Amyloid beta protein precursor and the pathogenesis of Alzheimer's disease. Cell 1989;58:611-612.

42. Cummings JL. Alzheimer's disease. $N$ Engl J Med 2004;351:56-67.

43. Rosales-Corral SA, Acuña-Castroviejo D, Coto-Montes A, Boga JA, Manchester LC, Fuentes-Broto L, et al. Alzheimer's disease: pathological mechanisms and the beneficial role of melatonin. J Pineal Res 2012;52:167-202.

44. Aliev G, Palacios HH, Walrafen B, Lipsit AE, Obrenovic ME, Morales L. Brain mitochondria as a primary target in the development of treatment strategies for Alzheimer disease. Int J Biochem Cell Biol 2009;41:1989-2004.

45. Masters CL, Selkoe DJ. Biochemistry of amyloid $\beta$-protein and amyloid deposits in Alzheimer disease. Cold Spring Harb Perspect Med 2012;2:a006262.

46. Hardy J, Selkoe DJ. The amyloid hypothesis of Alzheimer's disease: progress and problems on the road to therapeutics. Science 2002;297:353-356.

47. Tanzi RE, Bertram L. Twenty years of the Alzheimer's disease amyloid hypothesis: a genetic perspective. Cell 2005; 120:545-555.

48. Meyer-Luehmann M, Spires-Jones TL, Prada C, Garcia-Alloza M, de Calignon A, Rozkalne A, et al. Rapid appearance and local toxicity of amyloid-beta plaques in a mouse model of Alzheimer's disease. Nature 2008;451: 720-724.

49. Spires-Jones T, Knafo S. Spines, plasticity, and cognition in Alzheimer's model mice. Neural Plast 2012;2012:319836.

50. Kocahan S, Akillioglu K. Effects of NMDA receptor blockade during the early development period on the retest performance of adult Wistar rats in the elevated plus maze. Neurochem Res 2013:38:1496-1500.

51. Hardy J, Cowburn R, Barton A, Reynolds G, Lofdahl E, O'Carroll AM, et al. Region-specific loss of glutamate innervation in Alzheimer's disease. Neurosci Lett 1987;73: 77-80.

52. Greenamyre JT, Young AB. Excitatory amino acids and Alzheimer's disease. Neurobiol Aging 1989;10:593-602.

53. Palmer AM, Gershon S. Is the neuronal basis of Alzheimer's disease cholinergic or glutamatergic? FASEB J 1990;4:2745-2752.

54. Cacabelos R, Takeda M, Winblad B. The glutamatergic system and neurodegeneration in dementia: preventive strategies in Alzheimer's disease. Int J Geriatr Psychiatry 1999;14:3-47.

55. Francis PT. Glutamatergic systems in Alzheimer's disease. Int $J$ Geriatr Psychiatry 2003;18:S15-S21.

56. Wenk GL, Parsons CG, Danysz W. Potential role of $N$-methyl-D-aspartate receptors as executors of neurodegeneration resulting from diverse insults: focus on memantine. Behav Pharmacol 2006;17:411-424.

57. Kowall NW, Beal MF. Glutamate-, glutaminase-, and taurine-immunoreactive neurons develop neurofibrillary 
tangles in Alzheimer's disease. Ann Neurol 1991;29:162167.

58. Bussière T, Giannakopoulos $\mathrm{P}$, Bouras C, Perl DP, Morisson JH, Hof PR. Progressive degeneration of nonphosphorylated neurofilament protein-enriched pyramidal neurons predicts cognitive impairment in Alzheimer's disease: stereologic analysis of prefrontal cortex area 9. J Comp Neurol 2003;463:281-302.

59. Revett TJ, Baker GB, Jhamandas J, Kar S. Glutamate system, amyloid $\beta$ peptides and tau protein: functional interrelationships and relevance to Alzheimer disease pathology. J Psychiatry Neurosci 2013;38:6-23.

60. Braak H, Braak E, Yilmazer D, de Vos RA, Jansen EN, Bohl J, et al. Amygdala pathology in Parkinson's disease. Acta Neuropathol 1994;88:493-500.

61. Dodd PR, Scott HL, Westphalen RI. Excitotoxic mechanisms in the pathogenesis of dementia. Neurochem Int 1994;25:203-219.

62. Hölscher C. Possible causes of Alzheimer's disease: amyloid fragments, free radicals, and calcium homeostasis. Neurobiol Dis 1998;5:129-141.

63. Butterfield DA, Pocernich CB. The glutamatergic system and Alzheimer's disease: therapeutic implications. CNS Drugs 2003;17:641-652.

64. Parsons CG, Danysz W, Quack G. Glutamate in CNS disorders as a target for drug development: an update. Drug News Perspect 1998;11:523-569.

65. Danysz W, Parsons CG. The NMDA receptor antagonist memantine as a symptomatological and neuroprotective treatment for Alzheimer's disease preclinical evidence. Int J Geriatr Psychiatry 2003;18:S23-S32.

66. Mattson MP, Kumar KN, Wang H, Cheng B, Michaelis EK. Basic FGF regulates the expression of a functional 71 $k D a N M D A$ receptor protein that mediates calcium influx and neurotoxicity in hippocampal neurons. J Neurosci 1993; 13:4575-4588.

67. Collingridge GL, Singer W. Excitatory amino acid receptors and synaptic plasticity. Trends Pharmacol Sci 1990; 11:290-296.

68. Bliss TV, Collingridge GL. A synaptic model of memory: long-term potentiation in the hippocampus. Nature 1993; 361:31-39.

69. Decker H, Jürgensen S, Adrover MF, Brito-Moreira J, Bonfim TR, Klein WL, et al. N-methyl-D-aspartate receptors are required for synaptic targeting of Alzheimer's toxic amyloid- $\beta$ peptide oligomers. $J$ Neurochem 2010;115:1520-1529.

70. Kandel ER, Schwartz JH. Molecular biology of learning: modulation of transmitter release. Science 1982;218: 433-443.

71. Bliss TV, Lomo T. Long-lasting potentiation of synaptic transmission in the dentate area of the anaesthetized rabbit following stimulation of the perforant path. J Physiol 1973;232:331-356.

72. Lynch GS, Dunwiddie T, Gribkoff V. Heterosynaptic depression: a postsynaptic correlate of long-term potentiation. Nature 1977;266:737-739.

73. Malinow R. New developments on the role of NMDA receptors in Alzheimer's disease. Curr Opin Neurobiol 2012;22:559-563.

74. Snyder EM, Nong Y, Almeida CG, Paul S, Moran T, Choi $\mathrm{EY}$, et al. Regulation of NMDA receptor trafficking by amyloid-beta. Nat Neurosci 2005;8:1051-1058.

75. Shankar GM, Bloodgood BL, Townsend M, Walsh DM, Selkoe DJ, Sabatini BL. Natural oligomers of the alzheimer amyloid-beta protein induce reversible synapse loss by modulating an NMDA-type glutamate receptor-dependent signaling pathway. J Neurosci 2007;27:2866-2875.

76. Sun B, Halabisky B, Zhou Y, Palop JJ, Yu G, Mucke L, et al. Imbalance between GABAergic and glutamatergic transmission impairs adult neurogenesis in an animal model of Alzheimer's disease. Cell Stem Cell 2009;5: 624-633.

77. Wood JG, Mirra SS, Pollock NJ, Binder LI. Neurofibrillary tangles of Alzheimer disease share antigenic determinants with the axonal microtubule-associated protein tau (tau). Proc Natl Acad Sci U S A 1986;83:4040-4043.

78. Cárdenas AM, Ardiles AO, Barraza N, Baéz-Matus X, Caviedes P. Role of tau protein in neuronal damage in Alzheimer's disease and Down syndrome. Arch Med Res 2012;43:645-654.

79. Ihara Y, Nukina N, Miura R, Oqawara M. Phosphorylated tau protein is integrated into paired helical filaments in Alzheimer's disease. J Biochem 1986;99:1807-1810.

80. Iqbal K, Grundke-Iqbal I, Zaidi T, Merz PA, Wen GY, Shaikh SS, et al. Defective brain microtubule assembly in Alzheimer's disease. Lancet 1986;2:421-426.

81. Noble W, Pooler AM, Hanger DP. Advances in tau-based drug discovery. Expert Opin Drug Discov 2011;6:797-810.

82. Behl C. Brain aging and late-onset Alzheimer's disease: many open questions. Int Psychogeriatr 2012;24 Suppl 1:S3-S9.

83. Ittner LM, Götz J. Amyloid- $\beta$ and tau--a toxic pas de deux in Alzheimer's disease. Nat Rev Neurosci 2011;12:65-72.

84. Götz J, Ittner A, Ittner LM. Tau-targeted treatment strategies in Alzheimer's disease. Br J Pharmacol 2012; 165:1246-1259.

85. Ishihara $\mathrm{T}$, Hong $\mathrm{M}$, Zhang $\mathrm{B}$, Nakagawa $\mathrm{Y}$, Lee MK, Trojanowski JQ, et al. Age-dependent emergence and progression of a tauopathy in transgenic mice overexpressing the shortest human tau isoform. Neuron 1999;24:751-762.

86. Ishihara $\mathrm{T}$, Zhang $\mathrm{B}$, Higuchi $\mathrm{M}$, Yoshiyama $\mathrm{Y}$, Trojanowski JQ, Lee VM. Age-dependent induction of congophilic neurofibrillary tau inclusions in tau transgenic mice. Am J Pathol 2001;158:555-562.

87. Binde DK, Scharfman HE. Brain-derived neurotrophic factor. Growth Factors 2004;22:123-131.

88. Schindowski K, Belarbi K, Buée L. Neurotrophic factors in Alzheimer's disease: role of axonal transport. Genes Brain Behav2008;7 Suppl 1:43-56.

89. Phillips HS, Hains JM, Armanini M, Laramee GR, Johnson $\mathrm{SA}$, Winslow JW. BDNF mRNA is decreased in the hippocampus of individuals with Alzheimer's disease. Neuron 1991;7:695-702.

90. Murer MG, Yan Q, Raisman-Vozari R. Brain-derived neurotrophic factor in the control human brain, and in Alzheimer's disease and Parkinson's disease. Prog Neurobiol 2001;63:71-124.

91. Cai H, Cong WN, Ji S, Rothman S, Maudsley S, Martin B. Metabolic dysfunction in Alzheimer's disease and related neurodegenerative disorders. Curr Alzheimer Res 2012:9:5-17.

92. Zhang F, Kang Z, Li W, Xiao Z, Zhou X. Roles of brain-derived neurotrophic factor/tropomyosin-related kinase B (BDNF/TrkB) signalling in Alzheimer's disease. $J$ Clin Neurosci 2012;19:946-949.

93. Mu JS, Li WP, Yao ZB, Zhou XF. Deprivation of endogenous brain-derived neurotrophic factor results in impairment of spatial learning and memory in adult rats. Brain Res 1999;835:259-265. 
94. Alonso M, Vianna MR, Depino AM, Mello e Soiza T, Pereira P, Szapiro G, et al. BDNF-triggered events in the rat hippocampus are required for both short- and longterm memory formation. Hippocampus 2002;12:551-560.

95. Korte M, Carroll P, Wolf E, Brem G, Thoenen H, Bonhoeffer T. Hippocampal long-term potentiation is impaired in mice lacking brain-derived neurotrophic factor. Proc Natl Acad Sci U S A 1995;92:8856-8860.

96. Figurov A, Pozzo-Miller LD, Olafsson P, Wang T, Lu B. Regulation of synaptic responses to high-frequency stimulation and LTP by neurotrophins in the hippocampus. Nature 1996;381:706-709.

97. Knipper M, da Penha Berzaghi M, Blöchl A, Breer H, Thoenen H, Lindholm D. Positive feedback between acetylcholine and the neurotrophins nerve growth factor and brain-derived neurotrophic factor in the rat hippocampus. Eur J Neurosci 1994;6:668-671.

98. Wang HY, Stucky A, Liu J, Shen C, Trocme-Thibierge C, Morain P. Dissociating beta-amyloid from alpha 7 nicotinic acetylcholine receptor by a novel therapeutic agent, S 24795, normalizes alpha 7 nicotinic acetylcholine and NMDA receptor function in Alzheimer's disease brain. $J$ Neurosci 2009;29:10961-10973.

99. Eriksen JL, Janus CG. Plaques, tangles and memory loss in mouse models of neurodegeneration. Behav Genet 2007:37:79-100.

100. Chapman PF, White GL, Jones MW, Cooper-Blacketer D, Marshall VJ, Irizarry M, et al. Impaired synaptic plasticity and learning in aged amyloid precursor protein transgenic mice. Nat Neurosci 1999;2:271-276.

101. Hsia AY, Masliah E, McConlogue L, Yu GQ, Tatsuno G, $\mathrm{Hu} \mathrm{K}$, et al. Plaque-independent disruption of neural circuits in Alzheimer's disease mouse models. Proc Natl Acad Sci U S A 1999;96:3228-3233.

102. Roberson ED, Scearce-Levie K, Palop JJ, Yan F, Cheng $\mathrm{IH}, \mathrm{Wu} \mathrm{T}$, et al. Reducing endogenous tau ameliorates amyloid beta-induced deficits in an Alzheimer's disease mouse model. Science 2007;316:750-754.

103. King DL, Arendash GW, Crawford F, Sterk T, Menendez J, Mullan MJ. Progressive and gender-dependent cognitive impairment in the $A P P(S W)$ transgenic mouse model for Alzheimer's disease. Behav Brain Res 1999;103:145-162.

104. King DL, Arendash GW. Behavioral characterization of the Tg2576 transgenic model of Alzheimer's disease through 19 months. Physiol Behav 2002:75:627-642.

105. Hsiao K, Chapman P, Nilsen S, Eckman C, Harigaya Y, Younkin $\mathrm{S}$, et al. Correlative memory deficits, Abeta elevation, and amyloid plaques in transgenic mice. Science 1996;274:99-102.

106. Morgan D, Diamond DM, Gottschall PE, Ugen K, Dickey
$\mathrm{C}$, Hardly $\mathrm{J}$, et al. A beta peptide vaccination prevents memory loss in an animal model of Alzheimer's disease. Nature 2000;408:982-985.

107. Jawhar S, Trawicka A, Jenneckens C, Bayer TA, Wirths $\mathrm{O}$. Motor deficits, neuron loss, and reduced anxiety coinciding with axonal degeneration and intraneuronal $A \beta$ aggregation in the 5XFAD mouse model of Alzheimer's disease. Neurobiol Aging 2012;33:196.e29-196.e40.

108. Devi L, Ohno M. Phospho-eIF2 $\alpha$ level is important for determining abilities of $B A C E 1$ reduction to rescue cholinergic neurodegeneration and memory defects in 5XFAD mice. PLoS One 2010;5:e12974.

109. Pompl PN, Mullan MJ, Bjugstad K, Arendash GW. Adaptation of the circular platform spatial memory task for mice: use in detecting cognitive impairment in the APP $(S W)$ transgenic mouse model for Alzheimer's disease. $J$ Neurosci Methods 1999;87:87-95.

110. Corcoran KA, Lu Y, Turner RS, Maren S. Overexpression of hAPPswe impairs rewarded alternation and contextual fear conditioning in a transgenic mouse model of Alzheimer's disease. Learn Mem 2002;9:243-252.

111. Barnes P, Good M. Impaired pavlovian cued fear conditioning in Tg2576 mice expressing a human mutant amyloid precursor protein gene. Behav Brain Res 2005; 157:107-117.

112. Fratiglioni L, Paillard-Borg S, Winblad B. An active and socially integrated lifestyle in late life might protect against dementia. Lancet Neurol 2004;3:343-353.

113. Fratiglioni L, Wang HX, Ericsson K, Maytan M, Winblad B. Influence of social network on occurrence of dementia: a community-based longitudinal study. Lancet 2000;355: 1315-1319.

114. Stern Y. Cognitive reserve in ageing and Alzheimer's disease. Lancet Neurol 2012;11:1006-1012.

115. Brown J, Cooper-Kuhn CM, Kempermann G, Van Praag $\mathrm{H}$, Winkler J, Gage $\mathrm{FH}$, et al. Enriched environment and physical activity stimulate hippocampal but not olfactory bulb neurogenesis. Eur J Neurosci 2003;17:2042-2046.

116. van Praag H, Kempermann G, Gage FH. Running increases cell proliferation and neurogenesis in the adult mouse dentate gyrus. Nat Neurosci 1999;2:266-270.

117. van Praag H, Kempermann G, Gage FH. Neural consequences of environmental enrichment. Nat Rev Neurosci 2000;1:191-198.

118. Mayeux R, Stern Y. Epidemiology of Alzheimer disease. Cold Spring Harb Perspect Med 2012;2:a006239.

119. Scarmeas N, Levy G, Tang MX, Manly J, Stern Y. Influence of leisure activity on the incidence of Alzheimer's disease. Neurology 2001;57:2236-2242. 